\title{
Managers' Views on Environmental Management: An Examination of the Taiwanese Airline Industry
}

\author{
Fang-Yuan Chen ${ }^{1}$ \\ ${ }^{1}$ College of Construction and Development, Feng Chia University, Taichung, Taiwan, Republic of China \\ Correspondence: Fang-Yuan Chen, Department of Transportation Technology and Management, Feng Chia \\ University, Taiwan, Republic of China. E-mail: fychen@fcu.edu.tw
}

Received: November 22, $2012 \quad$ Accepted: December 23, 2012 Online Published: December 26, 2012
$\begin{aligned} & \text { doi:10.5539/jsd.v6n1p65 } \\ & \text { URL: http://dx.doi.org/10.5539/jsd.v6n1p65 }\end{aligned}$

\begin{abstract}
Air transport has made a major contribution to globalization and world economic growth. However, aircraft operations inevitably have a serious impact on the environment. Leading airlines have established policies, goals, and action plans on environmental management. This study uses a questionnaire survey to gain an understanding of the views and attitudes of airline managers in Taiwan toward environmental management. The results show that airline managers mostly have a positive and supportive attitude regarding environmental management, and believe that airlines can play an important role in environmental protection. The most important motivations for promoting environmental management are improving company image, reducing harm to the natural environment, and fulfilling corporate social responsibility, while the main obstacles to the development of environmental management are insufficient government grants, subsidies, and incentives, investment capital too high, and inadequate aviation environmental regulations. This study also reveals that the government should take a more proactive role in the development of Taiwanese airlines' environmental management.
\end{abstract}

Keywords: airlines, environmental protection, environmental management, sustainability

\section{Introduction}

Air transport has made a major contribution to globalization and world economic growth. However, aircraft consume energy, cause high levels of noise, and release a large amount of exhaust, all of which has a serious impact on the environment (Mayor \& Tol, 2009; Lassen, 2010; Cowper-Smith \& de Grosbois, 2011). Projected air travel growth in coming decades has made corporate environmental management a particularly important issue for the airline sector (Lynes \& Dredge, 2006). In 2007, the International Air Transport Association (IATA) put forward the Four-Pillar Strategy to deal with these impacts. The strategy brings together airlines, aircraft and engine manufactures, air traffic controllers, airports, and other stakeholders in a major effort to improve environmental performance. It is hoped that by 2020, the goal of carbon-neutral growth can be achieved (IATA, 2007).

In terms of environmental protection, leading airlines have established policies, goals, and action plans on environmental management. For instance, as early as 1992, Cathay Pacific had issued an official declaration on environmental protection, setting out a series of environmental commitments and goals. Delta, United, Singapore Airlines, Japan Airlines, and Korean Air have also established internal environmental management systems, responsible for planning, implementing, and auditing environmental management performance. In addition, customer and investor expectations and demands have led to the promotion of environmental management as a competitive strategy of product differentiation for airlines (Johnstone \& Labonne, 2009). International airlines operate across many countries and must comply with local environmental regulations wherever they do business. Environmental protection has become an important part of corporate social responsibility.

Current research on environmental management in the airline industry largely focuses on environmental protection practices (Li et al., 2003; Pitt \& Smith, 2003; El-Mobaidh et al., 2006; Gössling et al., 2009). There is relatively little work on the attitudes and beliefs of airline managers on environmental management. This study seeks to fill this gap by examining managerial views of environmental management issues and practices in Taiwan. Prior research has suggested that an individual's concern for and attitudes towards the environment affect his/her decision making (Bansal \& Roth, 2000; Sangle, 2010). If managers are concerned about the environment and have a positive attitude towards the issue, they are more likely to support corporate actions on 
environmental protection. Specifically, the overall objective of this study is to investigate the following research questions:

- What are the attitudes of airline mangers towards environmental management?

- How managers perceive the importance of environmental management performance for customers' choice of airline?

- What are the motivations and potential obstacles for promoting environmental management?

- To what degree do managers perceive pressure exerted by various stakeholders?

- Which organizations provide the most support for the development of environmental management in Taiwan?

\section{Literature Review}

\subsection{Environmental Management}

Environmental management refers to a continuous process adopted through management decisions, by which an organization's activities are monitored and appropriate programs and initiatives devised to reduce the negative impacts on the environment (Mensah, 2006). Environmental management is the process of taking steps, procedures, and behaviors to protect, enhance or reduce an organization's impact on the environment. Some have equated environmental management with Environmental Management Systems (EMS). EMS is a corporate approach based on auditing procedures, similar to the Plan-Do-Check-Act model of quality management, which involves setting objectives, measurable targets, a detailed program and a monitoring and evaluation process (Mensah, 2006; Chan \& Hawkins, 2012). The objective of EMS is to achieve a firm's continual improvement of its environmental behavior and performance (Massoud et al., 2010).

\subsection{Motivations for Promoting Environmental Management}

A number of reasons have been identified to explain why businesses participate in voluntary environmental initiatives. Miller (2001) investigated factors influencing environmental responsibility among tour operators in the United Kingdom and identified five major drivers: industry structure, legal requirements, market advantage/negative public relations, long-term cost savings, and moral obligation. Quazi et al. (2001) identified eight possible factors for predicting the motivation of companies to adopt ISO 14001 (Environmental Management System): cost savings, top management concern, employee welfare, meeting environmental regulations, meeting customer expectations, concern over trade barriers, following head office environmental practices, and gaining competitive advantages. In the airline context, Lynes \& Dredge (2006) interviewed top management of Scandinavian Airlines to identify the factors that shaped an airline's commitment to environmental management. These primary drivers are: the financial cost-benefit of environmental management, the regulatory setting, the desire to be a 'good corporate citizen', airline image, and relationships with the aviation community.

In view of the mentioned literature, the motivations for organizations to promote environmental management can be broadly classified into four main categories: the market drivers (e.g., green consumerism, cost reduction advantage), social drivers (e.g., community pressure, employee expectations), financial drivers (e.g., insurance coverage, financial damages), and regulatory drivers (e.g., environmental regulations, public disclosure requirements) (Bansal \& Howard, 1997). Although a variety of motivations have been identified, it must be noted that the reasons to promote environmental management may be industry dependent, which relies on the nature of the decision that needs to be made (Lynes \& Dredge, 2006; Zutshi \& Sohal, 2004).

\subsection{Obstacles to Implementing Environmental Management}

Massoud et al. (2010) assessed the factors influencing the implementation of ISO 14001 in the food industry in Lebanon. The results revealed that the primary barriers to adopting ISO 14001 included: lack of government support and incentives, benefits of certification are not clear or justifiable, the certification is not required legally, and the absence of customer demand. Zutshi \& Sohal (2004) summarized the barriers experienced by organizations when implementing environmental management as follows: cost consideration, lack of support and resources, unclear guidelines for environmental management implementation, lack of set guidelines for setting of objectives and targets, lack of guidelines on how to accomplish continuous improvement, and interpretation of terms present within the standard. Kasim (2007) investigated the barriers to implement environmental management in the hotel sector of Penang, Malaysia. He identified three major barriers: the nature of Malaysia's tourism industry and hotel sector, the lack of physical infrastructure support, and lack of conviction about corporate environmentalism. 


\section{Environmental Management Initiatives in the Taiwanese Airline Industry}

The environmental protection measures of Taiwanese airlines follow international and domestic regulatory norms, and are mostly focused on the prevention of noise pollution, air pollution, effluent, waste, and poisonous chemicals. Environmental management responsibilities are usually shared between relevant departments. In response to the greenhouse effect and market pressure, Taiwanese airlines have in recent years begun systematic efforts to develop environmental management.

The concrete measures adopted by Taiwanese airlines can be categorized as follows:

(1) Select environmentally friendly aircraft when purchasing new aircraft or replacing old aircraft.

(2) Reducing the weight of the aircraft: for instance using lightweight food trolleys, plates, and cutlery; only taking sufficient water and fuel for the flight; and using lighter paper for the in-flight magazine and duty-free magazine to reduce weight.

(3) Flight operations: for example increasing engine performance, reducing use of auxiliary power units (APU), using an economic cruising altitude, planning fuel- saving flight paths.

(4) Green buildings: Construction of new buildings on the basis of green architecture and energy-saving design.

Paperless measures: Promoting e-tickets, electronic official documents, e-freight, and electronic flight bags to reduce use of paper.

(6) Participate in domestic environmental activities and international environmental research projects.

China Airlines, Taiwan's largest international carrier, has made environmental management a focus of business operations since 2007 and put forward four major environmental objectives (complying with laws and regulations, saving sustainable resources, increasing eco-efficiency, and fulfilling social responsibility) and six environmental policies. Beginning in 2009, the airline has carried out a regular greenhouse gas inventory and verification in order to gain an understanding of the source and volume of greenhouse gas emissions in everyday operations. The airline has received "Reasonable Assurance" certification from the Environmental Protection Administration (EPA) in Taiwan. In 2011, China Airlines established an "Environmental Management Section" and recruited outside experts to establish green targets and strategies for each company unit. In 2012, the ISO14001 environmental management system was introduced to allow the continuous improvement in environmental performance. In terms of cabin services, China Airlines has actively promoted green in-flight services, including sourcing local ingredients for meal preparation, providing eco-friendly hand towels on all flights, encouraging passengers to take home reusable chopsticks, and providing reusable cups for use in-flight. In addition, China Airlines has participated in the Pacific Greenhouse Gases Measurement project to promote international environmental protection research. In this project, China Airlines has installed monitoring devices on an A340-300 aircraft to automatically collect and record atmospheric gases during flights, becoming the first airline in Asia and second in the world to do this.

EVA Airways is Taiwan's second largest carrier. As part of the Evergreen Group, it has recognized the adverse impact of the transportation industry on the environment at an early stage, learning from Evergreen's experience in the shipping industry. As a result, EVA has spared no effort in promotion of environmental management. In 2003, EVA began a fleet modernization program, purchasing completely new fuel-saving and low noise aircraft. The airline also established a "Fuel and Emission Reduction Committee" directly convened by the company president and general manager. The committee introduced measures including reducing aircraft weight, adjusting aircraft operating procedures, optimizing flight routes, selecting closer alternate airports, and reducing APU use in order to increase fuel efficiency and reduce greenhouse gas emissions. As a result of various fuel saving and carbon reduction measures, a total of 116,000 tons of fuel consumption was saved between 2007 and 2011, the equivalent of a 365,000 ton reduction in carbon dioxide emissions. Furthermore, EVA Airways has actively promoted an e-freight project, becoming an IATA e-freight airline operator in 2009. In 2000, EVA's catering services achieved ISO14001 environmental management system accreditation, using the highest standards to offer environmentally friendly in-flight meals and drinks.

In terms of environmental education, Taiwanese airlines often use mediums such as official company websites, information guides, and email to transmit and communicate environmental issues to their employees, with the hope that environmental protection becomes a part of employees' lives. In order to develop environmental consciousness among employees, China Airlines held a company-wide "Staff Environmental Protection" education and training activities in September 2011. These activities were aimed at strengthening staff awareness and creating consensus. In addition, following the spirit of the Environmental Education Act (passed in 2010 which requires public authorities, public enterprises, schools at high school level and below, and institutes which 
receive more than $50 \%$ of funding from the government to provide at least four hours of environmental education a year to staff, teachers, and students), the company has set aside time for basic environmental education for employees since 2012.

In the past, Taiwanese airlines tended to keep a low profile when dealing with environmental issues. Information provided to the public on the efforts of airlines to protect the environment was typically limited to a simple description in the company annual report or a press release. In 2011, both China Airlines and EVA Airways introduced an area of their official websites dedicated to the environment, displaying more corporate environmental protection information, putting forward environmental policies and commitments, explaining concrete measures and approaches to environmental protection, and reporting actual performance. Nevertheless, at present neither company has plans to draft an annual environmental report.

\section{Research Method}

The way how Taiwanese airlines respond to environmental issues over the past few years makes it particularly suitable to the research objectives. Taiwanese airlines used to follow international and domestic regulatory norms in their environmental work and environmental management responsibilities are shared between relevant departments. In response to market pressure, Taiwanese airlines have since taken a more proactive stance on environmental planning and implementation. It is worth investigating airline managers' views and beliefs on shaping organizational outcomes in relation to environmental issues.

This study used two approaches to data collection. First, we conducted several in-depth interviews with experts in the field. The topics covered in the interviews included the participants' attitudes towards environmental management, the motives behind their organization's efforts in environmental initiatives, the extent of pressure the stakeholders place on them, and the advantages and obstacles they perceived when implementing environmental management initiatives in their organizations. The results of the interviews provided a thorough understanding of the participants' perspectives concerning their organization' endeavors in environmental management initiatives. Following this, the questionnaire was developed on the basis of the interviews along with a review of the relevant literature.

Because of the small sample size, we did not carry out a questionnaire pretest. The questionnaire has six parts: the first part asks respondents about their attitudes towards environmental management; the second part asks respondents what criteria they believe are important for passengers when they choose an airline; the third part asks respondents about the assistance airlines companies have received in developing environmental management; the fourth part asks respondents about their feelings regarding the amount of pressure exerted by different stakeholders on environmental management; the fifth part asks respondents about the motivations for developing environmental management; and the sixth part asks respondents about obstacles to the development of environmental management. Respondents answer on a five-point scale depending on their level of agreement, with 1 representing "strongly disagree" and 5 representing "strongly agree."

Survey subjects were managers from four domestic airlines responsible for environmental management, including directors, managers, assistant managers, and researchers. During the survey period, questionnaires were distributed to the contact person at each of the airlines, who was asked to pass them on to individuals qualified to complete the questionnaire within the company. Respondents sealed completed questionnaires in a prepared envelope and returned them to the contact person. The questionnaires were then collected by the researcher in person or sent back to the researcher by post. The survey period was between February and May, 2011. Thirty questionnaires were distributed to each airline company, with a total of sixty questionnaires returned. After questionnaires with incomplete answers had been excluded, forty-eight questionnaires were used for analysis, giving an effective response rate of $40 \%$.

\section{Results}

\subsection{Attitudes towards Environmental Management}

The attitude of respondents towards environmental management is shown in Table 1. Although Taiwan is still at early stage in the development environmental management, the results show that airline managers mostly have a positive and supportive attitude towards environmental management. They recognize the importance of environmental issues and believe that protecting the natural environment is an important dimension of corporate social responsibility. They also believe that although environmental management increases expenditures, innovation in this area distinguishes the company from its competitors and achieves product differentiation (Sakr et al., 2010; Brammer et al., 2012), as well as increasing perceived customer value. Therefore, environmental management represents a window of opportunity for the company. It should also be noted that respondents 
generally reject the proposition that the company need only pay attention to environmental management when its profitability is good (Kasim, 2007). However, they also believe that service quality should not be sacrificed at the expense of promoting environmental management. Furthermore, respondents believe that environmental protection requires collective effort and relying on only one airline cannot produce any substantial results.

Table 1. Attitudes towards environmental management

\begin{tabular}{lcc}
\hline Question item & Mean & $\begin{array}{c}\text { Standard } \\
\text { deviation }\end{array}$ \\
\hline $\begin{array}{l}\text { Airlines must try to protect the natural environment. } \\
\begin{array}{l}\text { Striving to protect the natural environment is an important social } \\
\text { responsibility for airlines. }\end{array}\end{array}$ & 4.32 & 0.63 \\
$\begin{array}{l}\text { When airlines fulfill their environmental responsibilities, it can increase } \\
\text { perceived customer value. }\end{array}$ & 4.32 & 0.53 \\
$\begin{array}{l}\text { Although implementing environmental management will increase } \\
\text { expenditure, it is also an opportunity that airlines should make full use of. }\end{array}$ & 4.19 & 0.63 \\
$\begin{array}{l}\text { The efforts of } \\
\text { impact on environmental protection }\end{array}$ & 4.19 & 1.08 \\
$\begin{array}{l}\text { Environmental issues are very important for airlines. } \\
\text { Promotion of environmental management is a type of innovation which } \\
\text { can increase the company's product and service differentiation. }\end{array}$ & 4.14 & 0.71 \\
$\begin{array}{l}\text { Environmental management cannot sacrifice service quality and customer } \\
\text { satisfaction. }\end{array}$ & 4.05 & 0.63 \\
$\begin{array}{l}\text { The company need only pay attention to environmental management when } \\
\text { its profitability is good. }\end{array}$ & 2.49 & 1.02 \\
\hline
\end{tabular}

\subsection{Perceived Importance of Criteria when Choosing an Airline}

Respondents were asked which criteria they believed were important for passengers when choosing an airline. Respondents generally believe that flight safety, company image, service quality, and ticket prices are the most important criteria for passengers when choosing an airline, while environmental management performance is less important than these criteria. In other words, respondents do not think that currently passengers regard the quality of environmental management as an important criterion when they decide which airline to fly with. The results are shown in Table 2.

Table 2. Level of importance of different criteria when choosing an airline

\begin{tabular}{lccc}
\hline \multicolumn{1}{c}{ Criteria } & Mean & $\begin{array}{c}\text { Standard } \\
\text { deviation }\end{array}$ & Ranking \\
\hline Flight safety & 4.84 & 0.55 & 1 \\
Company image & 4.32 & 0.58 & 2 \\
Service quality & 4.11 & 0.74 & 3 \\
Ticket price & 4.08 & 0.83 & 4 \\
Airline's environmental management & 3.92 & 0.83 & 5 \\
performance & & & \\
Route network & 3.86 & 0.75 & 6 \\
Frequent flyer program & 3.70 & 0.74 & 7 \\
Membership of airline alliance & 3.59 & 0.80 & 8 \\
\hline
\end{tabular}




\subsection{Assistance Received to Promote Environmental Management}

As Table 3 shows, respondents generally believe that their companies do not receive much assistance to promote environmental management. The greatest assistance come from international aviation organizations (such as IATA and ICAO), followed by environmental groups and academic institutions. The government and airline trade associations are not viewed as major supporting organizations.

Table 3. Assistance received to promote environmental management

\begin{tabular}{lccc}
\hline \multicolumn{1}{c}{ Criteria } & Mean & $\begin{array}{c}\text { Standard } \\
\text { deviation }\end{array}$ & Ranking \\
\hline International aviation organizations & 3.62 & 0.86 & 1 \\
Environmental groups & 3.62 & 0.86 & 2 \\
Academic institutions & 3.49 & 0.77 & 3 \\
Environmental management accreditation & 3.46 & 0.84 & 4 \\
organizations & & & 5 \\
Government & 3.43 & 0.87 & 6 \\
Airline trade associations & 3.30 & 0.87 & 7 \\
Consultancy firms & 3.19 & 0.74 & 7 \\
\hline
\end{tabular}

\subsection{Pressure from Stakeholders}

Survey results show that respondents generally believe that stakeholder pressure on the promotion of environmental management is not very high. The greatest pressure comes from the government, followed by environmental groups, the mass media, competitors, and the local community. Pressure from consumers, suppliers, and distributors (travel operators) tends to be low. Results are shown in Table 4.

Table 4. Pressure from stakeholders

\begin{tabular}{lccc}
\hline \multicolumn{1}{c}{ Stakeholders } & Mean & $\begin{array}{c}\text { Standard } \\
\text { deviation }\end{array}$ & Ranking \\
\hline Government & 3.76 & 0.72 & 1 \\
Environmental groups & 3.73 & 0.65 & 2 \\
The mass media & 3.65 & 0.89 & 3 \\
Competitors & 3.38 & 0.79 & 4 \\
Local community & 3.22 & 0.95 & 5 \\
Shareholders and investors & 3.19 & 0.78 & 6 \\
Airline trade associations & 3.16 & 0.60 & 7 \\
Consumers & 3.11 & 0.84 & 8 \\
Company employees & 3.05 & 0.74 & 9 \\
Suppliers & 3.00 & 0.67 & 10 \\
Distributors (travel operators) & 2.86 & 0.95 & 11 \\
Financial institutions & 2.73 & 0.87 & 12 \\
\hline
\end{tabular}

\subsection{Motivations for Promoting Environmental Management}

As Table 5 shows, respondents state that the most salient drivers to motivate their airlines to promote environmental management are "improving company image", "reducing harm to the environment", and "fulfilling corporate social responsibility", followed by "complying with environmental regulations" and 
"beneficial to sustainable operations". Reducing long-term costs and meeting customer needs are not important motivations.

Table 5. Motivations for promoting environmental management

\begin{tabular}{lccc}
\hline Motivations & Mean & $\begin{array}{c}\text { Standard } \\
\text { deviation }\end{array}$ & Ranking \\
\hline Improving company image & 4.38 & 0.59 & 1 \\
Reducing harm to the environment & 4.32 & 0.63 & 2 \\
Fulfilling corporate social responsibility & 4.30 & 0.57 & 3 \\
Compliance with environmental & 4.22 & 0.53 & 4 \\
regulations & & & 5 \\
Beneficial to sustainable operations & 4.19 & 0.52 & 6 \\
Providing employees with a safe work & 4.03 & 0.69 & 7 \\
environment & & & 8 \\
Helping entry into other markets & 4.00 & 0.71 & 9 \\
As a marketing tool & 3.97 & 0.65 & 10 \\
Providing differentiated products and & 3.95 & 0.71 & 11 \\
services & & & 12 \\
Increasing competitive advantage & 3.86 & 0.67 & \\
Satisfying customer demands & 3.68 & 0.71 & \\
Reducing long-term costs & 3.62 & 0.98 & \\
\hline
\end{tabular}

\subsection{Obstacles to the Development of Environmental Management}

Table 6. Obstacles to the development of environmental management

\begin{tabular}{lccc}
\hline Obstacles & Mean & $\begin{array}{c}\text { Standard } \\
\text { deviation }\end{array}$ & Ranking \\
\hline $\begin{array}{l}\text { Insufficient government grants, subsidies, } \\
\text { and incentives }\end{array}$ & 4.32 & 0.58 & 1 \\
Investment capital too high & 4.08 & 0.60 & 2 \\
Inadequate aviation environmental & 3.84 & 0.60 & 3 \\
regulations & & & 4 \\
Unclear benefits & 3.81 & 0.91 & 5 \\
Pressure from consumers not large & 3.57 & 0.84 & 6 \\
Insufficient company expertise & 3.38 & 0.92 & 7 \\
Company set aside insufficient funding & 3.38 & 0.79 & 8 \\
Insufficient employee training and & 3.35 & 0.95 & 9 \\
education & & & 10 \\
Insufficient company communication & 3.35 & 1.00 & 11 \\
Concern that service quality will be & 3.35 & 0.98 & 12 \\
impacted & & & \\
Insufficient support from senior managers & 3.19 & 0.97 & \\
Company environmental policies and & 3.19 & 0.85 & \\
objectives are unclear & & & \\
\hline
\end{tabular}


Respondents believe that the main obstacles to the development of environmental management are insufficient government grants, subsidies, and incentives, investment capital too high, and inadequate aviation environmental regulations, followed by unclear benefits, pressure from consumers not large, and insufficient company expertise.

\section{Discussion}

This study extends the environmental management literature by investigating the attitudes and beliefs of Taiwanese airline managers towards environmental management. Although Taiwanese airlines have only started promoting environmental management in recent years, our survey results show that airline managers mostly have a positive and supportive attitude towards environmental management, and believe that airlines can play an active role in environmental protection. While external pressure on environmental issues is a threat to airlines, it is also an opportunity for change. It is believed that protecting the natural environment embodies the fulfillment of corporate social responsibility. Respondents also think that their companies have established clear environmental policies and goals, while senior managers attach a great deal of importance to environmental issues and have high levels of support for and commitment towards environmental management. Given that the concern of senior managers towards environmental protection plays a key role in the positive outcomes of a firm's environmental performance (Bansal \& Roth, 2000; Lynes \& Dredge, 2006; Papagiannakis \& Lioukas, 2012), we expect that this would assist in Taiwanese airlines' future promotion of environmental management.

From an institutional pressures perspective, domestic stakeholders do not exert a high degree of pressure on the issue of environmental management. Among them, respondents feel that pressure from the government is the greatest (Zhang et al., 2008). This pressure defines the actual environmental efforts undertaken by airlines. Pressure from consumers is not high either. Flight safety and company image are the main priorities for passengers when choosing an airline rather than environmental issues. This finding is consistent with the work by Lynes \& Dredge (2006) who indicated that pressure from passengers was not a factor influencing Scandinavian Airlines' promotion of environmental management. One possible explanation is that Taiwanese consumers are not as aware of the environmental impact of the aviation industry when compared to other industries (e.g., the manufacturing or petrochemical industry). This low level of pressure explains why consumers do not regard the quality of an airline's environmental management as an important factor when choosing an airline and why satisfying customer demands is not an important motivation for airlines to promote environmental management. Our results also show that the levels of both pressure and assistance from airline trade associations are low. This demonstrates that local airline trade associations should assume more proactive roles in both educating Taiwanese airlines on environmental issues and further communicating new practices or trends within the industry. In contrast, the government, environmental groups, and the mass media are the main sources of pressure behind airlines' promotion of environmental management. Environmental groups and the mass media have a big influence in Taiwan. For instance, in 2011, the government cancelled the second phase of the Kuokuang petrochemical project after continued pressure form environmental groups and media reporting.

Respondents generally believed that at the present stage, government assistance on environmental management was not significant. Environmental regulations in Taiwan are mostly focused on noise pollution, air pollution, and effluent produced by manufacturing industry (e.g., Air Pollution Control Act, Waste Disposal Act, Soil and Groundwater Pollution Remediation Act). Although relevant regulations requiring business compliance have been drawn up, the "Greenhouse Gas Reduction Act" has still not been passed by the legislature. As a result, the government can only use moral persuasion and guidance, helping airlines to comply with international civilian aviation and European norms, as well as carry out related planning and make appropriate responses. Therefore, the government (including the Ministry of Transportation and Communications, the Environmental Protection Administration, and the Civil Aeronautics Administration) has a key role to play, including the provision of policy support and incentive measures. By providing adequate support and incentives, the government can encourage the development of environmental management.

Taiwanese airlines are motivated to promote environmental management for three main reasons: "improving company image", "reducing harm to the natural environment", and "fulfilling corporate social responsibility". These results correspond to the research findings of Quazi et al. (2001) and Lynes \& Dredge (2006). Airlines able to apply environmental management to reduce harm to the natural environment have the opportunity to improve their overall company image (Babiak \& Trendafilova, 2011; Brammer et al., 2012). At the same time, these companies can strengthen relationships with stakeholders, including regulatory agencies, customers, suppliers, and the local community. Both China Airlines and EVA Airways regard implementing environmentally sustainable development as an important part of an airline's social responsibility. Another motivation, "compliance with environmental regulations," is enshrined in China Airlines' environmental 
philosophy. The importance of "providing staff with a safe work environment" is a unique finding of this study. EVA Airways regards this as an important company environmental commitment; it can be regarded as an added benefit in the promotion of environmental management which can help increase staff satisfaction. However, in contrast to previous research (Massoud et al., 2010), this study did not find that reducing costs was an important motivation for promoting environmental management.

Based on the analysis, the tope three barriers to promoting environmental management include "insufficient government grants, subsidies, and incentives", "investment capital too high", and "inadequate aviation environmental regulations". Respondents might be concerned that excessive investment costs in the early stages of implementing environmental management could affect company profitability (Kirk, 1998; Mensah, 2006; Brammer et al., 2012). This result is consistent with the findings of Massoud et al. (2010). Taiwanese airlines have only started to pay close attention to environmental management in recent years. Insufficient relevant environmental information makes it difficult to assess environmental performance. Hence, establishing a long-term database is necessary to assess the outcomes and benefits of environmental management initiatives, which might support management decisions to further promote environmental management. Besides, some respondents expressed concern that environmental management could affect service quality. For instance, some in-flight services may be cut back (e.g., not handing out milk and sugar unless requested), resulting in passenger misgivings. Therefore, avoiding such conflicts by maintaining a quality service for passengers while also fulfilling environmental responsibilities is an area that airlines need to think about carefully (Kasim, 2007).

\section{Conclusion and Recommendations}

The objective of this study is to understand the beliefs and attitudes regarding environmental management of Taiwanese airline managers working in areas related to environmental protection. The research results show that the respondents generally believed that senior managers at airline companies recognize the trend towards environmental protection and strongly support the promotion of environmental management. Taiwanese airlines have actively implemented a range of environmental and carbon reduction measures and have achieved some initial results. However, Taiwan has still not yet established comprehensive environmental regulations for the airline industry. As a result, airlines lack a local policy framework to guide environmental management, and can only concentrate their efforts on complying with international norms. Hence, policy makers and regulatory agencies should take a leading role in proving relevant laws and regulations for the airlines to follow. In the past, the environmental protection work of airlines was mostly focused on prevention of different types of pollution and was the responsibility of each relevant department. To comply with international trends towards sustainable operations, it is necessary to either move up the organizational level of current environmental unit or establish a unified department solely responsible for environmental issues, as well as to recruit the best talent in this area.

Although Taiwanese airlines have achieved some initial results in the promotion of environmental management, it was not possible to assess precisely environmental management performance due to the limited time frame. This presents an important area for future research. In addition, the sample in this study came directly from Taiwanese airline managers. The results may not reflect airline managers' views in different companies or regions. In the future, similar comparative surveys could be carried out in countries and regions elsewhere.

\section{Acknowledgement}

This research was financially supported by the National Science Council of Taiwan, Republic of China under Contract No. NSC 99-2410-H-035-055.

\section{References}

Babiak, K., \& Trendafilova, S. (2011). CSR and environmental responsibility: motives and pressures to adopt green management practices. Corporate Social Responsibility and Environmental Management, 18(1), 11-24. http://dx.doi.org/10.1002/csr.229

Bansal, P., \& Howard, E. (1997). Business and the Natural Environment. Butterworth Heinemann, Oxford.

Bansal, P., \& Roth, K. (2000). Why companies go green: a model of ecological responsiveness. Academy of Management Journal, 43(4), 717-736. http://dx.doi.org/10.2307/1556363

Brammer, S., Hoejmose, \& Marchant, K. (2012). Environmental management in SMEs in the UK: practices, pressures and perceived benefits. Business Strategy and the Environment, 21(7), 423-434. http://dx.doi.org/10.1002/bse.717

Chan, E. S. W., \& Hawkins, R. (2012). Application of EMS in a hotel context: A case study. International Journal of Hospitality Management, 31(2), 405-418. http://dx.doi.org/10.1016/j.ijhm.2011.06.016 
Cowper-Smith, A., \& de Grosbois, D. (2011). The adoption of corporate social responsibility in the airline industry. Journal of Sustainable Tourism, 19(1), 59-77. http://dx.doi.org/10.1080/09669582.2010.498918.

El-Mobaidh, A. M., Taha, M. A. R., \& Lassheen, N. K. (2006). Classification of in-flight catering wastes in Egypt air flights and its potential as energy source. Waste Management, 26(6), 587-591. http://dx.doi.org/10.1016/j.wasman.2005.02.022

Gössling, S., Haglund, L., Kallgren, H., \& Revahl, M. (2009). Swedish air travelers and voluntary carbon offsets: towards the co-creation of environmental value? Current Issues in Tourism, 12(1), 1-10. http://dx.doi.org/10.1080/13683500802220687

International Air Transport Association. (2007). Building a greener future.

Johnstone, N., \& Labonne, J. (2009). Why do manufacturing facilities introduce environmental management systems? Improving and/or signaling performance. Ecological Economics, 68(3), 719-730. http://dx.doi.org/10.1016/j.ecolecon.2008.06.003

Kasim, A. (2007). Corporate environmentalism in the hotel sector: evidence of drivers and barriers in Penang, Malaysia. Journal of Sustainable Tourism, 15(6), 680-699. http://dx.doi.org/10.2167/jost575.0

Kirk, D. (1998). Attitudes to environmental management held by a group of hotel managers in Edinburgh. $\begin{array}{lllll}\text { International Journal of Hospitality } & \text { Management, } & \text { 17(1), } & 33-47 .\end{array}$ http://dx.doi.org/10.1016/S0278-4319(98)00005-X

Lassen, C. (2010). Environmentalists in business class: an analysis of air travel and environmental attitude. Transport Review, 30(6), 733-751. http://dx.doi.org/10.1080/01441641003736556

Li, X. D., Poon, C. S., Lee, S. C., Chung, S. S., \& Luk, C. F. (2003). Waste reduction and recycling strategies for the in-flight services in the airline industry. Resources, Conservation, and Recycling, 37(2), 87-99. http://dx.doi.org/10.1016/S0921-3449(02)00074-5

Lynes, J. K., \& Dredge, D. (2006). Going green: motivations for environmental commitment in the airline industry. A case study of Scandinavian airlines. Journal of Sustainable Tourism, 14(2), 116-138. http://dx.doi.org/10.1080/09669580608669048

Massoud, M. A., Fayad, R., El-Fadel, M., \& Kamleh, R. (2010). Drivers, barriers and incentives to implementing environmental management systems in the food industry: A case of Lebanon. Journal of Cleaner Production, 18(3), 200-209. http://dx.doi.org/10.1016/j.jclepro.2009.09.022

Mayor, K., \& Tol, R. S. J. (2003). Aviation and the environment in the context of the EU-US Open Skies

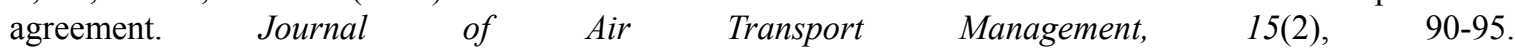
http://dx.doi.org/10.1016/j.jairtraman.2008.09.018

Mensah, I. (2006). Environmental management practices among hotels in the greater Accra region. International Journal of Hospitality Management, 25(3), 414-431. http://dx.doi.org/10.1016/j.ijhm.2005.02.003

Miller, G. (2001). Corporate responsibility in the UK tourism industry. Tourism Management, 22(6), 589-598. http://dx.doi.org/10.1016/S0261-5177(01)00034-6

Papagiannakis, G., \& Lioukas, S. (2012). Values, attitudes and perceptions of managers as predictors of corporate environmental responsiveness. Journal of Environmental Management, 100, 41-51. http://dx.doi.org/10.1016/j.jenvman.2012.01.023

Quazi, H. A., Khoo, Y. K., Tan, C. M., \& Wong, P. S. (2001). Motivation for ISO 14000 certification: $\begin{array}{lllll}\text { development of a } & \text { Omega, 29(6), 525-542. }\end{array}$ http://dx.doi.org/10.1016/S0305-0483(01)00042-1

Smith, A. (2003). Waste management efficiency at UK airports. Journal of Air Transport Management, 9(2), 103-111. http://dx.doi.org/10.1016/S0969-6997(02)00063-7

Sakr, D. A., Sherif, A., \& El-Haggar, S. M. (2010). Environmental management systems' awareness: an investigation of top 50 contractors in Egypt. Journal of Cleaner Production, 18(3), 201-218. http://dx.doi.org/10.1016/j.jclepro.2009.09.021

Sangle, S. (2010). Empirical analysis of determinants of adoption of proactive environmental strategies in India. Business Strategy and the Environment, 19(1), 51-63. http://dx.doi.org/10.1002/bse.651 
Zhang, B., Bi, J., Yuan, Z., Ge, J., Liu, B., \& Bu, M. (2008). Why do firms engage in environmental management? An empirical study in China. Journal of Cleaner Production, 16(10), 1036-1045. http://dx.doi.org/10.1016/j.jclepro.2007.06.016

Zutshi, A., \& Sohal, A. (2004). Environmental management system adoption by Australasian organizations: part 1: reasons, benefits, and impediments. Technovation, 24(4), 335-357. http://dx.doi.org/10.1016/S0166-4972(02)00053-6 